\title{
JUAL BELI SECARA ONLINE DALAM TINJAUAN HUKUM ISLAM
}

\author{
Wahibatul Maghfuroh \\ Universitas Panca Marga Probolinggo \\ Email: Wahibatulmaghfuroh@upm.ac.id
}

Diterima: 06-06-2020 | Direvisi: 15 Juni 2020 | Disetujui: 19 Juni 2020

(C) 2020 Program Studi Ahwal Syakhshiyyah Fakultas Agama Islam Universitas Islam Malang

\begin{abstract}
Abstrak
Transaksi online adalah transaksi pesanan dalam model bisnis era global yang tidak bertatap muka, dengan hanya melakukan transfer data melalui dunia maya (data intercange) melalui internet antara dua pihak, yaitu penjual dan pembeli, perkembangan teknologi informasi ini memungkinkan remote transaksi, di mana siapa pun dapat berinteraksi bahkan tanpa tatap muka (tatap muka). Dalam bisnis online yang terpenting adalah ketersediaan informasi dan manfaatnya. Atau yang sekarang lebih dikenal dengan e-bisnis atau e-commerce, jenis penelitian yang digunakan dalam penelitian ini adalah penelitian perpustakaan, jual beli online termasuk aspek muamalah yang pada dasarnya diperbolehkan. Kecuali ada argumen yang melarangnya. Selain itu, syarat dan ketentuan perjanjian pembelian online juga tidak bertentangan dengan syarat dan ketentuan sistem keterlibatan hukum Islam.
\end{abstract}

Kata Kunci: Jual Beli, Online, halal, haram

\begin{abstract}
Abstrack
Online transactions are order transactions in a global era business model that is not face-to-face, with only conducting data transfers via cyberspace (data intercange) via the internet between the two parties, namely sellers and buyers, this information technology development enables remote transactions, where anyone can interact even without face to face (face to face). In online business the most important thing is the availability of information and the benefits. Or what is now better known as ebusiness or e-commerce, the type of research used in this research is library research, buying and selling online including aspects of muamalah which are basically permissible. Unless there is an argument forbidding it. In addition, the terms and conditions of online purchase agreement also do not conflict with the terms and conditions of the Islamic legal system of engagement.
\end{abstract}

Keywords: Buying and Selling, Online, halal, haram

This work is licensed under Creative Commons Attribution Non Commercial 4.0 International License Available online on: http://riset.unisma.ac.id/index.php/fai/index 


\section{A. Pendahuluan}

Jual beli merupakan transaksi antara satu dengan yang lainnya dengan suka rela antara kedua nya atau disebut juga antaradin sebagaimana didalam sabda rasulullah SAW. Adalah sebagai berikut:

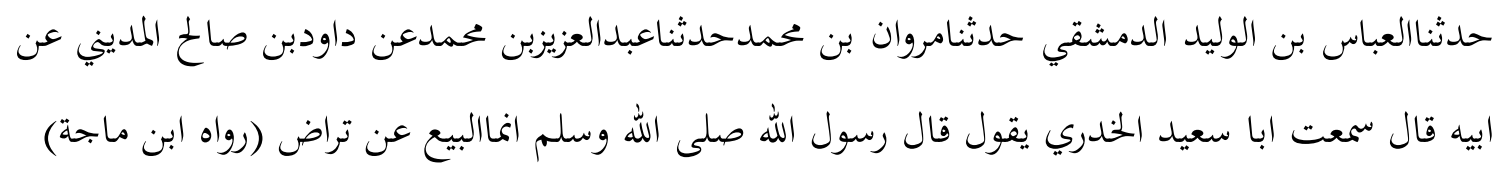

Hadis diatas menjelaskan bahwa jual beli itu didasarkan atas suka sama suka ('an taradin). Jadi, antara penjual dan pembeli saling merelakan apa yang telah disepakatinya.

Kegiatan praktek ekonomi tersebut berlangsung sangat lama dari zaman barter menukar barang dengan barang guna untuk kebutuhan keberlangsungan hidup dalam kehidupan sehari-hari, Akan tetapi sistem jual beli barter sudah ditinggalkan semenjak ada uang sebagai alat tukar menukar antara barang dan uang.

Seiring bejalannya waktu teknologi semakin canggih sehingga perubahanperubahan sangat maju. Kemudian manusia menemukan ATM, sehingga membeli dengan menggunakan transfer melewati ATM, bisa juga dengan menggunakan HP dengan nominal uang yang telah ditetapkan secara online.

Pada saat ini, jual beli online sudah menjadi kebiasaan masyarakat sekitar kita, kita tinggal lihat gambar-gambar, foto-foto barang yang mau dijual dengan melalui shoope, Face book, What App dan lain sebagainya, jika pembeli setuju tinggal transfer, kemudian barang dipaketin lewat Pos, JNE dan lain sebagainya. Hal ini merupakan ada unsur kerelaan antara pembeli dan penjual, jika barang tidak sesuai dengan apa yg ada di foto, menurut saya ini tergantung perjanjian dari awal, yang terpenting saling merelakan satu sama lain atau disebut dengan 'antaradin.

Kemajuan jual beli online atau disebut online shop sangat berkembang pesat. Bahkan, hampir seluruh perdagangan barang-barang semua melalui online dengan memakai internet, baik bisa dilakukan dengan Hp android maupun laptop.

JAS: Volume 2 Nomor 1, 2020 
Bentuk jual beli seperti ini banyak sisi positif, yaitu kedua belah pihak tidak harus bertemu, cukup dengan melakukan online, gambar barang tinggal kirim lewat Whats App, Face Book, Intagram, shoope dan lain sebagainya, sehingga pembeli tinggal melihat di HP maupun dilaptop.semuanya serba praktis, tinggal duduk manis, tanpa harus bertemu.uang tinggal transfer lewat ATM Banking.

Dengan adanya jual beli online diharapkan untuk ketertiban transaksi jual beli, disamping itu, untuk memudahkan dalam jual beli, betapa majunya zaman pada saat ini, semua serba online, praktis, cepat, mudah, perubahan-perubahan seperti ini sangat berdampak positif baik penjual maupun pembeli.

Ada juga sisi negatif dari jual beli online ini, kadang tidak sesuai dengan gambar yang sudah diuploud, sehingga konsumen kecewa dg barangnya. Digambar kelihatan bagus ketika dikirim lewat pos barangnya tidak sesuai. Ini merupakan kelemahan jika beli lewat online.

Kejadian-kejadian seperti yang telah dijelaskan diatas merupakan kemajuan-kemajuan teknologi pada zaman sekarang ini, memberi kemudahan bagi penjual dan pembeli, bahkan bukan hanya jual beli saja, kegaiatan-kegiatan yang lain juga serba online, inilah kelebihan-kelebihan teknologi yang diciptakan oleh manusia sekarang.

Penelitian ini mendeskripsikan bentuk akad yang telah diterapkan oleh kedua belah pihak penjual dan pembeli yang terkait jual beli online kemudian Menganalisa jual beli online perspektif Hukum Islam, dan kesimpulan menarik titik temu Hasil Penelitian.

\section{B. Metode}

Jenis penelitian yang digunakan adalah penelitian kepustakaan (library research), dengan menggunakan pendekatan teologi normative (syar'i), yaitu pendekatan dengan menggunakan nash yaitu, al-quran, as-sunah/al-hadits, Ijma' dan Qiyas.

\section{Hasil dan Pembahasan}

\section{Akad dan Jual Beli dalam Islam}

Akad berasal dari kata bahasa arab yaitu al-'Aqdu yaitu perjanjian atau perikatan. Sayyid Sabiq (93:1995) literature fikih sunah menjelaskan bahwa akad merupakan perjanjian atau kesepakatan. Ada literatur lain mengatakan (63:2001) bahwa akad ('al-aqdu) merupakan suatu perjanjian ataupun suatu 
kontrak antara kedua belah pihak antara penjual dan pembeli, bisa juga dikatakan ijab dan qabul, ijab adalah seseorang yang melaksanakan perikatan atau perjanjian antara kedua belah pihak sedangkan Kabul adalah penerimaan terhadap perjanjian tersebut.

Menurut Mustafa Ahmad az-zarqa memberi penjelasan dalam ensiklopedi hukum islam (63:2001), Menjadi 2 macam tindakan hukum yang dilakukan oleh seseorang. Diantaranya:

1. Tindakan berupa Ucapan:

a. Bersifat akad: kedua belah pihak mengikatkan perjanjian diri untuk melakukan kesepakatan.

b. Tidak bersifat akad:

1) pemilik bisa melimpahkan hak, membatalkan, ataupun menggugurkan.

2) Tidak mengandung unsur kemauan antara kedua belah pihak tetapi prakteknya mengandung suatu perjanjian atau perikatan, ini juga berdampak suatu hukum yang mengikat antara kedua belah pihak.

2. Tindakan yang berupa perbuatan

Jual beli merupakan kegiatan sehari-hari, tidak luput dengan transaksi antara penjual dan pembeli, karena saling membutuhkan antara satu dengan yang lainya, sehingga penjual membutuhkan konsumen/ pembeli, begitu juga pembeli butuh barang nya yang di inginkan, sehingga, kegiatan jual beli sangat penting artinya saling membutuhkan.

Untuk lebih jelasnya pengertian tentang jual beli, ada beberapa pengertian dari jual beli, antara lain yang telah dikemukakan oleh Taqiyyuddin (279:2001), Zainuddin (316:2004), Dimyauddin (92:2008), dan Sabiq (92:1995), bahwa jual beli adalah transaksi antara penjual dan pembeli yaitu pertukaran barang dengan barang, harta dengan harta, dengan mengikat atau membuat perjanjian antara kedua belah pihak, dan yang di tukar memberi kemaslahatan antara kedua belah pihak.

\section{Rukun, Syarat, dan Dasar hukum jual Beli}

JAS: Volume 2 Nomor 1, 2020 
Menurut Haroen (111:2001) di dalam buku Fiqh Muamalah Transaksi Jual beli dalam literatur fiqh disebut dengan lafadz al-bai'u yaitu jual beli, bisa juga dikatakan, tukar menukar, adapun menurut Ulama' Hanifiyah jual beli adalah "tukar menukar sesuatu yang diingini dengan yang sepadan atau setara melalui cara tertentu yang bermanfaat". Yang dimaksud ijab dan qabul adalah saling memberi ketentuan barang dan harga dan memberi kemaslahatan antara kedua belah pihak. Sebagaimana di dalam sebuah hadits:

$$
\text { ان الله ورسوله حرم بيع الخمر والميتة والخنزيروالأصنام }
$$

"sesungguhnya Allah dan Rasul-nya mengharamkan jual beli khamr, bangkai, babi dan patung" (Muttafaq 'alaih).

Misalnya riba. Allah SWT. Berfirman:

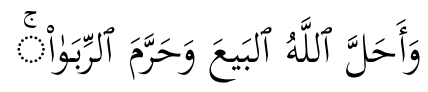

"Allah menghalalkan jual beli dan mengharamkan riba." (Q.S albaqarah: 275)

Menurut Hendi Suhendi (70: 2001) bertransaksi jual beli harus memenuhi rukun dan syaratnya. Adapun Rukun jual beli yaitu sesuatu yang harus ada setiap perbuatan hukum. Rukun jual beli tersebut terdapat tiga macam.

a. Ijab dan Kabul (akad).

b. Penjual dan Pembeli

c. Objek akad (ma'qud alaih)

\section{Pengertian Jual Beli dengan Akad Salam Secara Online}

Transaksi melalui online merupakan transaksi tanpa tertatap muka langsung oleh penjual dan pembeli, hanya melakukan transfer data lewat media sosial antara kedua pihak yaitu penjual dan pembeli, kemajuan teknologi informasi seperti pada saat inilah yang biasa memungkinkan transaksi jarak jauh, siapapun dan dimanapun dapat berinteraksi walaupun tanpa tatap muka (face to face). Yang terpenting komunikasi jangan sampai 
terputus supaya tidak hilang antara penjual dan pembeli dalam melakukan transaksi online. Oleh karena itu, pada zaman sekarang teknologi sangat canggih, tinggal duduk manis, dan pilah pilih barang yang diinginkan.

Gambar jual beli online

\begin{tabular}{|c|c|c|}
\hline \multirow{2}{*}{ 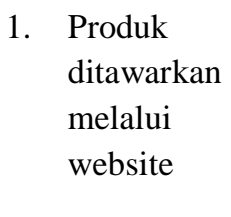 } & & \multirow{2}{*}{$\begin{array}{l}\text { 2. Pembeli membeli } \\
\text { produk dari penjual }\end{array}$} \\
\hline & \multirow{2}{*}{$\begin{array}{l}\text { 3.Bayar } \\
\text { (produk+ongkos } \\
\text { kirim) }\end{array}$} & \\
\hline \multirow[t]{2}{*}{ Penjual } & & Pembeli \\
\hline & Kirim & \\
\hline
\end{tabular}

\section{Kelebihan dan kekurangan Jual Beli Online}

Transaksi jual beli online mempunyai kelebihan dan kekurangan masing masing. Adapun kelebihan jual beli secara online yaitu:

1. Memberi kemudahan dalam bertransaksi antara penjual dan pembeli

2. Tidak membutuhkan waktu yang lama

3. Hemat biaya

Disisi lain, kelebihan transaksisi online adalah mempunyai saling kepercayaan antara penjual dan pembeli. Kekurangannya adalah banyak penipuan-penipuan dalam melakukan transaksi online, kadang antara gambar/foto yang dikirim tidak sama dengan barangnya. Ini juga harus pintar dalam memilah dan memilih barang online, apalagi pada saat ini kamera HP luar biasa indahnya, jadi barang yang tidak bagus juga tampak kelihatan bagus nan indah. Kasus-kasus seperti ini secara tidak langsung juga bersifat penipuan karena tidak menampakkan foto barang sesungguhnya.

\section{Tinjauan Hukum Islam terhadap Jual beli Online}

JAS: Volume 2 Nomor 1, 2020 
Jual Beli Secara Online dalam Tinjauan Hukum Islam

Dari penjelasan diatas bahwa ketidak bolehan transaski secara online karena ketidak jelasan tempat dan ketidakhadirannya antara penjual dan pembeli.

Akan tetapi kita mencoba menghubungkan antara al-quran, As-ssunah atau al-hadits, Ijma' dan Qiyas, yang berlandaskan: "pada awalnya semua muamalah diperbolehkan sehingga ada dalil yang menunjukkan keharamannya".

Sebagaimana perkataan Abdullah bin Mas'ud: apa yang dipandang baik oleh seseorang maka itu baik, sebaliknya juga apa yang dipandang buruk oleh seseorang itu buruk. Dan yang paling penting adalah kejujuran, keadilan, dan kejelasan dengan memberikan data-data secara akurat, lengkap dan tidak ada niatan untuk menipu atau merugikan orang lain, sebagaimana di dalam surat al-baqarah ayat 275 dan 282.

Syarat-syarat jual beli secara Islam sah, halal dan diperbolehkan oleh Syari'at Islam yaitu harus memenuhi langkah-langkah sebagai berikut, diantaranya:

a. Produk Halal.

b. Kejelasan Status.

c. Kesesuaian harga dengan kualitas barang.

d. Kejujuran anda.

\section{Simpulan}

Transaksi jual beli online merupakan muamalah, hukumnya boleh (mubah). Jual beli online tidak bertentangan dengan nash dan ini merupakan bentuk suatu kemaslahatan dan saling menguntungkan. dalam kitab fikih, sesungguhnya di dalam literature telah telah disebutkan Ulama' menyepakati transaksi melalui surat maupun perantara. Kemudian kasus-kasus seperti di qiyaskan dengan jual beli transaksi online melewati FB, What App, Instagram, Shoope dan lain sebagainya, yang terpenting adalah saling merelakan antara keduanya atau disebut dengan 'antaradin, saling keterbukaan, dan kejujuran dalam melaksanakan kegiatan bertransaksi.

\section{Daftar Rujukan}

JAS: Volume 2 Nomor 1, 2020 
Wahibatul Maghfuroh

Aziz Dahlan, Abdul, dkk, Ensiklopedi Hukum Islam, Jakarta: Ichtiar Baru Van Hoeve, 2001

Djuwaini, Dimyaudin , Pengantar Fiqh Muamalah, Yogyakarta: Pustaka Pelajar 2008.

Haroen, Hasrun, Fiqh Muamalah, Jakarta: Gaya Media Pratama.

Haroen, Nasrun, Fiqh Muamalah, Jakarta: Gaya Media Pratama, 2000.

Shomad, Abd. , Hukum Islam: Penormaan Prinsip Syariah dalam Hukum Indonesia, (Bandung: Kencana, 2017.

Siswadi, Jual Beli dalam Perspektif Islam, Jurnal Ummul Qura, Vol. 3 (2).

Suhendi, Hendi, Fiqh mualmalah, Jakarta: PT. Raja Grafindo Persada.

Warson Munawwir, Ahmad, Kamus al-Munawwir Arab-Indonesia lengkap, Surabaya: Pustaka Progresif, 1997.

Zainuddin, Ahmad bin Aziz, Abdul, Fathu alMu"in, Beirut: Dar Ibn Hazm, 2004.

JAS: Volume 2 Nomor 1, 2020 